\title{
Persistent urethritis due to Ureaplasma urealyticum in conjugal or stable partnerships
}

\author{
O P ARYA* AND B C PRATT $\dagger$
}

From the *Department of Genitourinary Medicine, Royal Liverpool Hospital, and the $†$ Department of Medical Microbiology, University of Liverpool, Liverpool

SUMMARY A study of four conjugal partnerships is described in which the male partners presented with persistent or recurrent non-gonococcal, non-chlamydial, but ureaplasma positive urethritis. Resolution of symptoms and signs in the male partners was achieved only after treatment to eliminate Ureaplasma urealyticum from both partners.

\section{Introduction}

Of the mycoplasmal flora, Mycoplasma hominis and Ureaplasma urealyticum are the species most commonly isolated from the human genital tract in the presence or absence of disease. Though the aetiology of non-gonococcal urethritis in men has not been finally settled, $\boldsymbol{M}$ hominis has largely been dismissed as having no role in this disease. U urealyticum, on the other hand, may cause urethritis according to some workers, ${ }^{12}$ but only in a small proportion of people from whom the organism can be isolated. ${ }^{3}$ Attempts to explain this phenomenon by quantitative studies ${ }^{4}$ have provided conflicting results. In a detailed review, Taylor-Robinson and McCormack considered other explanations, including the possibility that only certain serotypes of $U$ urealyticum may be pathogenic or that the organism may be of low invasiveness, and hence clinically recognisable infection may result in only a small proportion of exposed men. ${ }^{1}$ No single explanation has yet proved satisfactory, however, and until the aetiological role of $U$ urealyticum in an individual patient is better defined, the indications for treatment will remain unclear, as will the optimum treatment and the need for contact tracing.

Our recent experience prompted us to undertake an investigation of men with persistent or recurrent urethritis and their female partners to try to clarify the situation concerning its cause and treatment.

Address for reprints: Dr O P Arya, Department of Genitourinary Medicine, Royal Liverpool Hospital, Prescot Street, Liverpool L7 8XP

Accepted for publication 29 January 1986

\section{Patients, materials, and methods}

Between July and December 1984, four men presented to the department of genitourinary medicine of the Royal Liverpool Hospital because of persistent or recurrent urethral discharge or urinary symptoms, despite treatment with various courses of antibiotics by their general practitioners or investigations and further treatment by urologists, or both. They were all seen by the same clinician (OPA) after whose persuasion the female partners of the patients also attended.

History and clinical examination included demographic data, past history, relevant history of exposure, details of treatment already received, and symptoms and signs.

\section{SPECIMENS TAKEN \\ Men}

Urethral specimens were collected with plastic loops for urethral smear for Gram staining and culture for Neisseria gonorrhoeae. Specimens for Chlamydia trachomatis, mycoplasmas, and herpes simplex virus were obtained with swabs made of sterile plain cotton wool on a thin metal wire (Medical Wire Equipment Co, Corsham, Wiltshire) inserted $3-5 \mathrm{~cm}$ into the urethra and rotated several times. Non-gonococcal urethritis was diagnosed if five or more polymorphonuclear leucocytes were seen in a high power field (magnification x 1000), Gram negative diplococci were not seen, and culture for Neisseria gonorrhoeae gave negative results. If chronic prostatitis was considered to be a possibility, prostate examination and tests were carried out using the segmented culture technique described by Meares and Stamey ${ }^{5}$ and Stamey. ${ }^{6}$ 


\section{Women}

Specimens were collected with cotton wool swabs from the urethra and cervix for smears for Gram staining and for culture for $\boldsymbol{N}$ gonorrhoeae and mycoplasmas, and from the cervix only for culture for $C$ trachomatis. Swabs from the vaginal vault instead of the cervix were obtained from one patient who had undergone hysterectomy. High vaginal swabs were also obtained for culture for Candida albicans and Trichomonas vaginalis.

Specimens of blood were taken from men and women for syphilis serology tests.

\section{LABORATORY INVESTIGATIONS}

\section{Culture methods}

Specimens were inoculated directly on to modified Thayer-Martin medium for culture for $\mathrm{Ngonorrhoeae}$. Swabs for culture for $C$ trachomatis, mycoplasmas, and herpes simplex virus were placed in their respective transport media and either processed immediately or stored frozen at $-70^{\circ} \mathrm{C}$ pending investigation.

Material for $C$ trachomatis isolation was inoculated on to cover slip cultures of cycloheximide treated McCoy cells. Specimens in A3xB transport medium ${ }^{7}$ for culture of mycoplasmas or ureaplasmas were inoculated into and then serially diluted in ten fold steps in Hayflick type broths. Broths for growth of $U$ urealyticum were adjusted to $\mathrm{pH} 6.0$ and contained $1 \%(w / v)$ urea, those for growth of $M$ hominis were adjusted to $\mathrm{pH} 7.4$ and contained $1 \%(\mathrm{w} / \mathrm{v})$ arginine dihydrochloride. Both broths contained $0.002 \%(\mathrm{w} / \mathrm{v})$ phenol red indicator. ${ }^{8}$ After incubation at $37^{\circ} \mathrm{C}$, broths showing colour change were subcultured to A7 agar $^{7}$ and mycoplasma agar to confirm the presence of ureaplasmas or mycoplasmas, or both. Specimens for herpes simplex isolation were inoculated into tubes of Vero tissue culture.

\section{Sensitivities to antibiotics}

Minimum inhibitory concentrations (MICs) of each ureaplasma isolate were measured against oxytetracycline, erythromycin, and doxycycline and were carried out in duplicate. The tests were performed in microtitre well plates and used a standardised ureaplasma inoculum of $10^{3}-10^{4}$ colour changing units $(\mathrm{ccu}) / \mathrm{ml}$. The antibiotics were diluted in two fold steps in urea broth. Plates were incubated at $37^{\circ} \mathrm{C}$ until colour changes in the wells were complete, the MIC being recorded as the concentration of antibiotic just preventing a colour change.

\section{TREATMENT}

The following regimens were used: (1) oxytetracycline or erythromycin $250 \mathrm{mg}$ orally four times daily for seven days, (2) oxytetracycline or erythromycin 500 mg orally four times daily for 10 days, or (3) doxycycline $200 \mathrm{mg}$ initially, followed by $100 \mathrm{mg}$ orally twice daily for $\mathbf{1 0}$ days. Details of the times of taking the tablets and their relation with food were emphasised.

\section{Results}

Three of the men (a businessman, a doctor, and a fireman) were married and one (a health inspector) was single but contemplating marriage. Their female partners included a teacher, a doctor, a sales assistant, and a full time housewife.

All men at the time of first attendance were experiencing urethral discharge or dysuria, or both; the women, however, were asymptomatic. None of the women had received an antibiotic during the preceding six weeks. All men and women had negative cultures for $\boldsymbol{N}$ gonorrhoeae, $C$ trachomatis, $M$ hominis, and $T$ vaginalis, but positive cultures for $U$ urealyticum. The numbers of $U$ urealyticum in the men ranged from $5 \mathrm{x}$ $10^{5}$ to $5 \times 10^{7} \mathrm{ccu} / \mathrm{ml}$ and in the women from $5 \times 10^{2}$ to $5 \times 10^{5} \mathrm{ccu} / \mathrm{ml}$. Cand albicans was isolated from one female patient. None of the men showed evidence of chronic prostatitis.

As the clinical features and laboratory findings of all four couples were broadly similar, only one couple is described in detail. A 28 year old man had been experiencing dysuria intermittently for one year. His general practitioner, after unsuccessfully treating him with several courses of oxytetracycline, referred him to a urologist. The urologist found his prostate and intravenous urogram to be normal, but urethroscopy showed a reddened urethra for which two further courses of oxytetracycline were prescribed. The condition recurred yet again and the patient was then referred to one of us (OPA). A detailed interview showed that this patient's symptoms usually recurred about a week after sexual intercourse with his finacée, with whom he had had a stable relationship for seven years. The table shows the sequence of events and the management of the couple after that interview.

As the man had already failed to respond to oxytetracycline, he was treated with erythromycin $250 \mathrm{mg}$ four times daily for one week, and the couple were advised to abstain from sexual intercourse during the course of treatment. Whereas the man remained ureaplasma negative after completing the course of erythromycin, the woman was persistently positive, despite receiving a total of two courses of oxytetracycline and one of erythromycin (see table). At this stage they were allowed and indeed encouraged to resume intercourse, which they did. Exactly seven days later the man's dysuria recurred, a Gram stained urethral smear showed excessive leucocytes, and a urethral swab was positive for ureaplasmas. Both partners were then treated with doxycycline $200 \mathrm{mg}$ initially followed by $100 \mathrm{mg}$ twice daily for 10 days. The man has remained asymptomatic ever since, and 
TABLE Sequence of events and management of one couple

\begin{tabular}{|c|c|c|c|}
\hline Date & Man & Date & Woman \\
\hline $\begin{array}{l}1984 \\
23 \text { July }\end{array}$ & 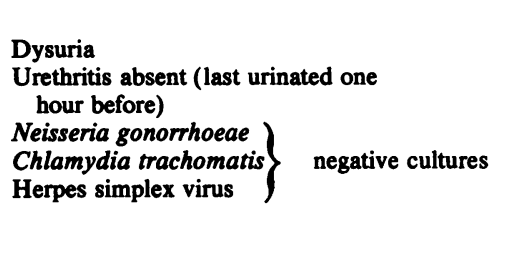 & $\begin{array}{l}1984 \\
25 \text { July }\end{array}$ & $\begin{array}{l}\text { No symptoms } \\
\text { Clinically normal } \\
\text { Neisseria gonorrhoeae } \\
\text { Chlamydia trachomatis } \\
\text { Trichomonas vaginalis } \\
\text { Candida albicans } \\
\text { Mycoplasma hominis } \\
\text { Ureaplasma urealyticum positive }\end{array}$ \\
\hline \multirow[t]{2}{*}{30 July } & $\begin{array}{l}\text { Dysuria } \\
\text { Urethritis present (last urinated } \\
\text { four hours before) } \\
\text { Mycoplasma hominis negative }\end{array}$ & & \\
\hline & $\begin{array}{l}\text { Ureaplasma urealyticum positive }\left(5 \times 10^{5} \mathrm{ccu} / \mathrm{ml}\right) \\
\text { Erythromycin } 250 \mathrm{mg} \text { four times } \\
\text { daily for } 7 \text { days }\end{array}$ & 1 Aug & $\begin{array}{l}\text { Oxytetracycline } 250 \mathrm{mg} \text { four } \\
\text { times daily for } 7 \text { days }\end{array}$ \\
\hline 10 Aug & No symptoms & & \\
\hline 28 Aug & $\begin{array}{l}\text { Urethritis absent } \\
U \text { urealyticum negative }\end{array}$ & $\begin{array}{l}22 \text { Aug } \\
29 \text { Aug }\end{array}$ & $\begin{array}{l}U \text { urealyticum positive }\left(5 \times 10^{1} \mathrm{ccu} / \mathrm{ml}\right) \\
\text { Erythromycin } 250 \mathrm{mg} \text { four times daily } \\
\text { for } 7 \text { days }\end{array}$ \\
\hline 10 Oct & $\begin{array}{l}\text { No symptoms } \\
\text { Urethritis absent } \\
U \text { urealyticum negative }\end{array}$ & $\begin{aligned} 3 \text { Oct } \\
15 \text { Oct }\end{aligned}$ & $\begin{array}{l}U \text { urealyticum positive }\left(5 \times 10^{3} \mathrm{ccu} / \mathrm{ml}\right) \\
U \text { urealyticum positive }\left(5 \times 10^{5} \mathrm{ccu} / \mathrm{ml}\right) \\
\text { Oxytetracyline } 500 \mathrm{mg} \text { four times } \\
\text { daily for } 10 \text { days }\end{array}$ \\
\hline $6 \mathrm{Nov}$ & $\begin{array}{l}\text { No symptoms } \\
\text { Urethritis absent } \\
U \text { urealyticum negative }\end{array}$ & 7 Nov & $U$ urealyticum positive $\left(5 \times 10^{3} \mathrm{ccu} / \mathrm{ml}\right)$ \\
\hline $8 \mathrm{Dec}$ & \multicolumn{3}{|c|}{ Sexual intercourse resumed } \\
\hline \multirow[t]{2}{*}{18 Dec } & $\begin{array}{l}\text { Dysuria for three days } \\
\text { Urethritis present }\end{array}$ & & \\
\hline & $\begin{array}{l}U \text { urealyticum positive }\left(5 \times 10^{4} \mathrm{ccu} / \mathrm{ml}\right) \\
\text { Doxycycline } 200 \mathrm{mg} \text { initially then } \\
100 \mathrm{mg} \text { twice daily for } 10 \text { days }\end{array}$ & $19 \mathrm{Dec}$ & $\begin{array}{l}\text { Doxycycline } 200 \mathrm{mg} \text { initially then } \\
100 \mathrm{mg} \text { twice daily for } 10 \text { days }\end{array}$ \\
\hline $\begin{array}{l}1985 \\
8 \mathrm{Jan}\end{array}$ & $\begin{array}{l}\text { No symptoms } \\
\text { Urethritis absent } \\
\text { U urealyticum negative }\end{array}$ & $16 \mathrm{Jan}$ & $U$ urealyticum negative \\
\hline 18 Feb & $\begin{array}{l}\text { No symptoms } \\
\text { Urethritis absent } \\
\text { U urealyticum negative }\end{array}$ & 27 Feb & $U$ urealyticum negative \\
\hline
\end{tabular}

follow up swabs from both of them 1,2 , and 9 months after treatment have remained negative for ureaplasmas.

Similarly, the symptoms and signs in the other three men and the infective agent ( $U$ urealyticum) in these men and their sexual partners did not clear until both partners had been adequately treated, which suggests that $U$ urealyticum was the cause of the recurrent urethritis in these men.

Oxytetracycline $250 \mathrm{mg}$ four times daily for seven days (in one man and three women) or $500 \mathrm{mg}$ four times daily for 10 days (in one woman) failed to eradi- cate $U$ urealyticum in any of the patients so treated. Erythromycin gave similar results in women: two were treated with erythromycin base $250 \mathrm{mg}$ four times daily for seven days, but both were still harbouring $U$ urealyticum after completing these courses. This contrasted with the man in whom the organism was cleared after treatment with erythromycin $250 \mathrm{mg}$ four times daily for seven days. He remained free of the organism for over four months, at which time he was considered to be reinfected.

The MICs for these strains, whether isolated before or after treatment, were typically $2-4 \mathrm{mg} / 1$ for oxyte- 
tracycline and $4 \mathrm{mg} / \mathrm{l}$ for erythromycin. The same strains, when tested against doxycycline, gave MICs in the range $0 \cdot 125-0.5 \mathrm{mg} / \mathrm{l}$. Doxycycline in the dosage regimen used $(200 \mathrm{mg}$ initially followed by 100 $\mathrm{mg}$ twice daily for 10 days) eradicated the organism in all cases.

\section{Discussion}

Our findings, which suggest a causative role for $U$ urealyticum in the recurrent urethritis experienced by a selected group of men in stable conjugal partnerships, are similar to those in the one case described by Ford and Henderson, ${ }^{10}$ except that in our investigation we were not able to serotype the isolates. Because of the ubiquitous nature of $U$ urealyticum, we agree with the view that routine swabbing of patients for these organisms is not really justifiable. ${ }^{11}$ Nevertheless, part of that same view suggested that $U$ urealyticum should be considered as a possible aetiological agent of nongonococcal urethritis in cases that fail to clear with tetracycline because tetracycline resistant strains are known to be circulating..$^{2}$ Our findings suggest that the management of such patients should be extended to include their female partners. The optimum treatment regimen for $U$ urealyticum infection is not known, but our limited experience presented in this study does suggest that oxytetracycline or erythromycin $250 \mathrm{mg}$ four times daily for one week are unsatisfactory, at least in women. This was perhaps surprising in view of the observed MICs of oxytetracycline and erythromycin for the $U$ urealyticum isolates as on the basis of these results no strain could be considered to be resistant. Relative resistance of $U$ urealyticum to tetracyclines has, however, been correlated with an MIC of 4-8 mg/1, ${ }^{8}$ and this could possibly explain the failure of oxytetracycline to eradicate the organism from either the cervix or from the male urethra in our patients.

In the case of erythromycin, the lower activity of this antibiotic at an acid $\mathrm{pH}$ has been suggested as a reason for its failure to eradicate $U$ urealyticum from the vagina, despite its effectiveness in removing the organism from the male urethra. ${ }^{13}$ This suggestion would seem to be borne out by our results, as in the case of the one couple detailed in the table the man's urethritis was successfully treated with erythromycin and he remained free of symptoms until reinfected by his sexual partner. This occurred despite the observed low MICs of erythromycin for the original isolates from both the man and woman. Treatment with doxycycline was completely effective in all patients, however, both men and women, and in none of the couples so treated has the man showed signs of relapse, nor has any of the couples shown evidence of recolonisation with $U$ urealyticum during nine months of follow up.
The partnerships presented here were not investigated for anaerobic organisms or for Mycoplasma genitalium $^{14}$ as possible causes of male urethritis, and these organisms should be borne in mind in interpreting the outcome of treatment, as should the possibility of an as yet unknown infective cause. Nevertheless, we believe our results serve to emphasise the importance of considering $U$ urealyticum as a cause of persistent non-gonococcal, non-chlamydial urethritis in men, and in addition point to the necessity for adequate treatment of both partners of the conjugal relationship to eliminate the signs and symptoms of the disease in the man.

We thank Mrs Karen Scott for her invaluable technical help throughout this investigation.

\section{References}

1. Taylor-Robinson D, McCormack WM. The genital mycoplasmas. N Engl J Med 1980;302:1003-10.

2. Taylor-Robinson D, Csonka GW, Prentice MJ. Human intraurethral inoculation of ureaplasmas. $Q J$ Med 1977; 46:309-26.

3. Coufalik ED, Taylor-Robinson D, Csonka GW. Treatment of nongonococcal urethritis with rifampicin as a means of defining the role of Ureaplasma urealyticum. British Journal of Venereal Diseases 1979;55:36-43.

4. Hunter JM, Smith IW, Peutherer JF, MacCauley A, Tauch S, Young H. Chlamydia trachomatis and Ureaplasma urealyticum in men attending a sexually transmitted diseases clinic. British Journal of Venereal Diseases 1981;57:130-3.

5. Meares EM Jr, Stamey TA, Bacteriological localisation patterns in bacterial prostatitis and urethritis. Investigative Urology 1968;5:492-518.

6. Stamey TA. Prostatitis. J Roy Soc Med 1981;74:22-40.

7. Shepard MC, Lunceford CD. Differential agar medium (A7) for identification of Ureaplasma urealyticum (human T mycoplasmas) in primary cultures of clinical material. J Clin Microbiol 1976;3:613-25.

8. Mårdh P-A. Bacteria, chlamydiae, and mycoplasmas. In: Holmes KK, Mårdh P-A, Sparling PF, Wiesner PJ, eds. Sexually transmitted diseases. London: McGraw-Hill, 1984:829-56.

9. Taylor-Robinson D, Furr PM. The static effect of rosaramicin on Ureaplasma urealyticum and the development of antibiotic resistance. J Antimicrob Chemother 1982;10:185-91.

10. Ford DK, Henderson E. Non-gonococcal urethritis due to T-mycoplasma (Ureaplasma urealyticum) serotype 2 in a conjugal sexual partnership. British Journal of Venereal Diseases 1976;52:341-2.

11. Taylor-Robinson D, McCormack WM. The genital mycoplasmas. N Engl J Med 1980;302:1063-7.

12. McCormack WM, Taylor-Robinson D. The genital mycoplasmas. In: Holmes KK, Mårdh P-A, Sparling PF, Wiesner PJ, eds. Sexually transmitted diseases. London: McGraw-Hill, 1984:408-21.

13. Russo ME, Thompson MIB. Pharmacology of drugs used in venereology. In: Holmes KK, Mårdh P-A, Sparling PF, Wiesner PJ, eds. Sexually transmitted diseases. London: McGraw-Hill, 1984:891-922.

14. Taylor-Robinson D, Furr PM, Hanna NF. Microbiological and serological study of non-gonococcal urethritis with special reference to Mycoplasma genitalium. Genitourin Med 1985;61:319-24. 